\title{
Characteristics of Neural Stem Cells Expanded in Lowered Oxygen and the Potential Role of Hypoxia-Inducible Factor-1Alpha
}

\author{
Cui-ping Zhang ${ }^{\text {a }}$ Ling-ling Zhu ${ }^{\text {a, }}$ Tong Zhao ${ }^{\text {a }}$ Huiqing Zhao ${ }^{\text {a }}$ Xin Huang ${ }^{\text {a }}$ \\ Xin $\mathrm{Ma}^{\mathrm{a}}$ Hai Wang ${ }^{\mathrm{b}, 2}$ Ming Fan ${ }^{\mathrm{a}}$ \\ a Department of Brain Protection and Plasticity, Institute of Basic Medical Sciences, and \\ ${ }^{b}$ Department of Physiology, Institute of Healthy Environment, Beijing, China
}

\section{Key Words}

Oxygen/hypoxia, lowered $\cdot$ Neural stem cells .

Hypoxia-inducible factor- $1 \cdot$ Differentiation

\begin{abstract}
It has recently been reported that hypoxia promotes the survival and proliferation of neural stem cells (NSCs). In the present study, we examine the differentiation ability of neural precursors expanded under lowered oxygen conditions, and the potential role of hypoxia-inducible factor (HIF)- $1 \alpha$ in vitro, which is the key molecule in response to lowered oxygen. The NSCs were cultured in a $3 \% \mathrm{O}_{2}$ environment for 3 days, and differentiated with $1 \%$ fetal bovine serum (FBS) for another 5-7 days, and the cell lineage was evaluated by immunohistochemistry, flow cytometry and HPLC. Compared with the normal condition, the NSCs cultured in hypoxia (3\% $\mathrm{O}_{2}$ ) displayed an increase in the percentage of neurons. Especially the percentage of $\mathrm{TH}$-positive neurons differentiated from NSCs in lowered oxygen increased significantly; the dopamine (DA) content in the medium was higher than under normal conditions. These data indicate that lowered oxygen favors dopaminergic differentiation. We then examined the expression of HIF-1 $\alpha$ during differentiation of NSCs. The levels of HIF-1 $\alpha$ mRNA expression under $3 \%$ oxygen did not change as compared with those under normal conditions. However, HIF-1 $\alpha$ protein expression was higher from 3 to $72 \mathrm{~h}$ during hypoxia than under normal conditions. Overexpression of HIF-1 $\alpha$ significantly increased the number of
\end{abstract}

TH-positive cells and the DA content in culture medium under normal conditions. These results suggest that HIF- $1 \alpha$ is involved in the regulation of dopaminergic differentiation of NSCs in lowered oxygen. This study may also offer a new approach to yield DA neurons using a physical factor.

Copyright $\odot 2007$ S. Karger AG, Basel

\section{Introduction}

Hypoxia can regulate cellular proliferation and differentiation. In recent years, some reports have described the salutary effects of mild hypoxia on neural progenitors $[1,2]$ or neurons $[3,4]$. However, the effects of hypoxia on stem cell characteristics remain to be fully understood. Morrison et al. [1] and Studer et al. [2] reported that oxygen lowered to more physiological levels (3\%) provides marked trophic and proliferative effects on neural precursors and significantly changes developmental kinetics and outcome compared with traditional culture conditions (20\%) [5]. Under hypoxic conditions, the differentiation of embryonic stem (ES) cells as well as precursor cells is inhibited [6-8]. Yun et al. [7,8] demonstrate that, under hypoxic conditions, pre-adipocytes treated with adipogenic hormones maintain their precursor phenotype and can fully commit to adipogenic differentiation upon returning to normoxia. They have also recently demonstrated that hypoxia reversibly arrests pre-adipocytes in an undifferentiated state [9]. We have also found

\section{KARGER}

Fax +4161306 1234 E-Mail karger@karger.ch www.karger.com (c) 2007 S. Karger AG, Basel

$1424-862 X / 06 / 0155-0259 \$ 23.50 / 0$

Accessible online at:

www.karger.com/nsg
Ming Fan

Department of Neurobiology, Institute of Basic Medical Sciences

27 Taiping Road, Beijing (China)

Tel. +86106821 4026, Fax +86 106821 3039, E-Mail fanming@nic.bmi.ac.cn

${ }^{1}$ Co-first author; ${ }^{2}$ co-corresponding author 
that hypoxia is capable of inducing the dopamine (DA) phenotype of bone marrow-derived mesenchymal stem cells and P19 cells $[10,11]$. These observations indicate that hypoxia plays a critical role in the maintenance and multi-lineage ability of the stem cell phenotype.

The cellular response to hypoxia is manifested by activation of the hypoxia-inducible factor-1 (HIF-1), a transcription factor of the basic helix loop-helix Per, AhR and Sim (bHLH-PAS) family [12]. HIF-1 consists of the $\mathrm{O}_{2}$ regulated HIF- $1 \alpha$ subunit and the $\mathrm{O}_{2}$-independent HIF$1 \beta$ subunit. Under hypoxic conditions, HIF- $1 \alpha$ is no longer hydroxylated and thus becomes stabilized. HIF- $1 \alpha$ activation results in increased expression of several key targeted genes such as erythropoietin, vascular endothelial growth factor, tyrosine hydroxylase (TH) and OCT4, which function as regulators of cellular proliferation and differentiation $[13,21,22]$. But the exact role of HIF- $1 \alpha$ in maintaining stem cells remains to be discovered.

In the present study, we investigated the effects of $3 \%$ oxygen on the characteristics of neural stem cells (NSCs) expanded under hypoxic conditions. To elucidate the role of HIF- $1 \alpha$ in the fate of hypoxia-induced NSCs, we examined the expression of HIF- $1 \alpha$ during differentiation induced by hypoxia, and the effect of HIF-1 $\alpha$ overexpression on the differentiation of NSCs.

\section{Materials and Methods}

Isolation and Culture of NSCs

Mesencephalon cells were dissected from Wistar rats on embryonic day 13.5 (E13.5) and mechanically dissociated. They were grown in DMEM/F12 (1:1) medium containing $2 \mathrm{mM}$ L-glutamine, $5 \mathrm{IU}$ penicillin, $5 \mu \mathrm{g} / \mathrm{ml}$ streptomycin (BioWhittaker), $1 \%$ N2 (Life Technologies), 1\% B27 (Life Technologies), 20 ng/ml EGF (Sigma) and $20 \mathrm{ng} / \mathrm{ml}$ bFGF (Invitrogen).

\section{Condition of Hypoxia}

For decreased oxygen cultures, an incubator (Thermo model 3110), which is adjustable for different oxygen concentrations, was used. The incubator was flushed with air containing $5 \% \mathrm{CO}_{2}$ and balanced with $\mathrm{N}_{2}$. The actual concentrations inside the incubator were 3 or $10 \%$ oxygen measured with a microelectrode (Animus Corp., Malvern, Pa., USA). The time of hypoxia was calculated from the measurement indicating the desired oxygen concentration.

\section{Differentiation and Immunohistochemistry}

For differentiation of NSCs, the 3rd to 5 th generations of NSCs were grown in the proliferation medium and divided into 2 groups. Then these NSCs were expanded either under hypoxia (3 and $\left.10 \% \mathrm{O}_{2}\right)$ or normal $\left(20 \% \mathrm{O}_{2}\right)$ conditions for the differentiation study, and the neural spheres were dissociated with $0.25 \%$ trypsinase after 3 days of culture. The cells were counted and planted on 35-mm dishes coated with polylysine at the same den- sity $\left(5 \cdot 10^{4} / \mathrm{ml}\right)$, and differentiated by $1 \%$ FBS for another $5-7$ days under normal conditions. The subtype of NeuN-positive cells was tested by immunocytochemistry.

For immunocytochemistry, the cells were fixed with $4 \%$ paraformaldehyde at $4^{\circ} \mathrm{C}$ for $2 \mathrm{~h}$ after 5-7 days of differentiation. Then the cells were pretreated with $5 \%$ of NHS to block the nonspecific binding and incubated with a mouse monoclonal antibody against NeuN (Molecular Probe, dilation 1:5,000) for $24 \mathrm{~h}$ at $4^{\circ} \mathrm{C}$. After washing in $0.1 \mathrm{M}$ phosphate buffer, the cells were then incubated with biotinylated anti-mouse IgG (Vector Laboratories, diluted $1: 1,000)$ at $4^{\circ} \mathrm{C}$ overnight. NeuN immunoreactivity was visualized as a black nuclear precipitate using a nickel-intensified 3,3-diaminobenzidine procedure [14]. The numbers of NeuNpositive cells and total cells were counted double-blindly ( 25 fields per dish) under $200 \times$ magnification using an electron microscope (Leica DC300). The analyses were repeated 4 times.

\section{Flow Cytometric Analysis}

Cells were treated with $0.25 \%$ trypsinase and collected in 15 $\mathrm{ml}$ tubes. After centrifugation, the pellet was resuspended in icecold $2 \%$ paraformaldehyde buffer. Normal goat serum was added to block nonspecific protein interactions. The cell suspension was then incubated with primary antibody (TH, dilution 1:500) in PBS for $1 \mathrm{~h}$, washed with PBST, and resuspended in $100 \mu \mathrm{lPBS}$ containing fluorescein isothiocyanate-conjugated goat antimouse secondary antibody (Santa Cruz, dilution 1:50). The cells were stained with secondary antibody for $60 \mathrm{~min}$ on ice, and assayed in PBS for flow cytometric analysis (FACSalibur, BD). The percentage of TH-positive cells was calculated.

High-Performance Liquid Chromatography Analysis

DA release was stimulated in HBSS containing $56 \mathrm{mM} \mathrm{KCl}$ for 15 min of incubation as described previously [14]. In brief, at the appropriate medium change, a sample of the culture medium was taken. Protein in the samples was precipitated with $0.4 \mathrm{M} \mathrm{HCl}$, and then the sample was centrifuged at $2,500 \mathrm{~g}$ for $10 \mathrm{~min}$ at $48^{\circ} \mathrm{C}$ followed by HPLC analysis. A Shimadzu solvent delivery system was used with the following mobile phase: $92 \% 75 \mathrm{mM} \mathrm{NaPO}_{4}, 1.7 \mathrm{mM}$ octane sulfonic acid, $0.05 \mathrm{mM}$ EDTA, pH 3.1, and 8\% acetonitril, at a flow rate of $0.8 \% \mathrm{ml} / \mathrm{min}$. An Alltech (Deerfield, Ill., USA) Absorbosphere HS C18 reverse phase column $(10 \times 4.6 \mathrm{~mm}$, $3 \mu \mathrm{m}$ ) was connected to an electrochemical detector (Coulochem II; ESA Inc., Chelmsford, Mass., USA). Results were normalized against DA standards at varying flow rates and sensitivity.

\section{RNA Extraction and Reverse Transcription-PCR}

Cultures were washed once with PBS before solubilization in Trizol (Life Technologies) and then stored at $-80^{\circ} \mathrm{C}$. RNA extraction was performed according to the recommendations of the manufacturer (Life Technologies). PCR conditions were optimized by varying the $\mathrm{MgCl}_{2}$ concentration and cycle number to determine the linear amplification range. Amplification products were identified by size and confirmed by DNA sequencing. The $\mathrm{MgCl}_{2}$ concentration was $1.5 \mathrm{mM}$ for HIF-1 $\alpha$. The program for PCR was as follows: primers for HIF- $1 \alpha 5^{\prime}$-TGCTTGGTGCTGATTTGTGA-3'， 5'-GGTCAGATGATCAGAGTCCA-3' were used to yield a 209 -bp product for 30 cycles at $58^{\circ} \mathrm{C}$; and $\mathrm{m} 18$ SRNA primer: forward 5' $5^{\prime}$ TTATGGTTCCTTTGGTCGCT-3' , reverse $5^{\prime}$-ATGTGGTAGCCGTTTCTCAG-3', was used to yield a 355 -bp product for 30 cycles at $56^{\circ} \mathrm{C}$. 
Fig. 1. Lowered oxygen increases the percentage of NeuN-positive cells. a Representative photograph of NeuN-positive cells differentiated from NSCs under normal conditions. b Representative photograph of NeuN-positive cells differentiated from NSCs under the $3 \%$ oxygen condition. Scale bar $=252 \mu \mathrm{m}$. Black granules are NeuN-positive cells. c Diagram showing the percentage of neurons. Each bar represents the mean $\pm \operatorname{SD}(\mathrm{n}=4) .{ }^{*} \mathrm{p}<$ 0.05 , as compared with control.

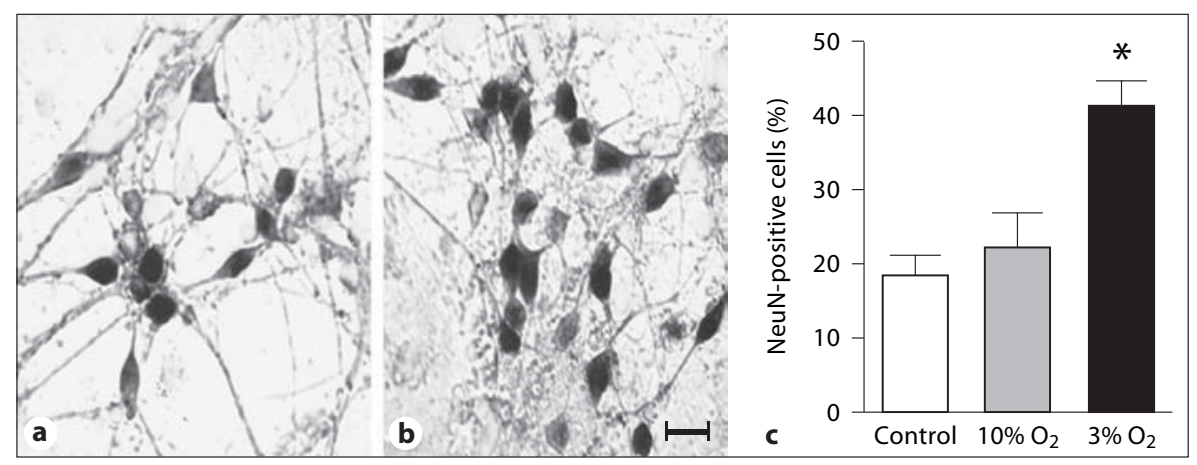

Protein Extraction and Western Blot

Cells were harvested quickly after either hypoxic or normoxic culture for the desired times and the total protein was extracted with lyses buffer, which contained $100 \mathrm{mM}$ Tris- $\mathrm{HCl}$ ( $\mathrm{pH}$ 7.5), $300 \mathrm{mM} \mathrm{NaCl}, 2 \%$ (v/v) Tween-20, 0.4\% NP-40, 20\% glycerol, supplemented with protease inhibitors $(1 \mu \mathrm{g} / \mathrm{ml}$ leupeptin and pepstatin, $2 \mu \mathrm{g} / \mathrm{ml}$ aprotinin and $1 \mathrm{mM}$ PMSF) and phosphatase inhibitors $\left(10 \mathrm{~mm} \mathrm{NaF}\right.$ and $\left.1 \mathrm{mM} \mathrm{Na}_{3} \mathrm{VO}_{4}\right)$. Then Western blot analyses were carried out. Extracts were quantified using a protein assay kit (Bio-Rad) and fractionated by $6 \%$ polyacrylamideSDS gel electrophoresis and transferred to a polyvinylpyrrolidone difluoride membrane (Immobilon-P, Millipore, Bedford, Mass., USA). The membrane was blocked with Tris-buffered saline (TBS-T) containing 5\% dry milk at room temperature for $2 \mathrm{~h}$. Membranes were incubated with anti-HIF-1 $\alpha$ mouse monoclonal antibody (Chemicon, dilution 1:500) in TBS-T containing $5 \%$ nonfat dry milk. Membranes were treated with goat antimouse secondary antibody conjugated with horseradish peroxidase (Santa Cruz; dilution 1:1,000) in TBS-T containing 5\% nonfat dry milk. Immune complexes were visualized using an enhanced chemiluminescence detection system (Amersham Biosciences).

Construction of Recombinant Adenoviral Vector Ad/HIF-1 $\alpha$ and Adenovirus Infection Assay

The recombinant adenoviral vector overexpressing the human HIF- $1 \alpha$ gene was a kind gift from Prof. Tang Hong (Institute of Microbiology, Chinese Academy of Science). The AdEasy system was used to generate recombinant adenovirus. The complete cDNA of human HIF-1 $\alpha$ was 3,720 bp in length, containing a 2,478 bp open reading frame and a 1,242 bp $5^{\prime}$ - and $3^{\prime}$-untranslated region. An open reading frame of $2,478 \mathrm{bp}$ which encoded a sequence of 826 amino acid residues was constructed into the recombinant adenoviral vector. The successfully recombinant adenoviral vector, digested with $P a c I$ to linearize the plasmid and ethanol precipitated, was used for transfection into HEK293 cells. The recombinant virus produced in HEK293 cells could then be further purified and tittered.

For the adenovirus infection assay, neurospheres were dissociated into single cells before infection with adenovirus. After 2hour incubation, the virus-containing medium was replaced by fresh complete growth medium. Then, the NSCs were cultured for $72 \mathrm{~h}$, and the expression of HIF-1 $\alpha$ was measured. The modified constructs contained HIF-1 $\alpha$ coupled to green fluorescent protein (GFP) in separate expression cassettes. The infection rate with the adenovirus was determined by the percentage of GFPpositive cells detected by flow cytometer.

\section{Statistical Analysis}

All the experiments were repeated at least three times, unless otherwise indicated. Data are presented as mean \pm SD. Statistical analysis was performed by $\mathrm{t}$ test. A statistical probability of $\mathrm{p}<$ 0.05 was considered significant.

\section{Results}

\section{Lowered Oxygen Promotes the Neuronal}

Differentiation of NSCs

We have reported that lowered oxygen $\left(10 \% \mathrm{O}_{2}\right.$ and $3 \%$ $\mathrm{O}_{2}$ ) promoted the proliferation of NSCs in vitro [10]; in the present study the differentiation ability of NSCs cultured under the lowered oxygen conditions was investigated. The NSCs were expanded under either lowered or $20 \% \mathrm{O}_{2}$ conditions for 3 days, and differentiated by $1 \%$ FBS without EGF and bFGF for another 5-7 days under normal conditions. The cell subtype was tested by immunocytochemistry. We found that the percentage of NeuNpositive cells in hypoxia increased significantly as compared with the normal group. These results show that lowered oxygen $\left(3 \% \mathrm{O}_{2}\right)$ markedly increases the yield of neurons (fig. 1).

\section{Lowered Oxygen Increases the Yield of TH-Positive \\ Neurons and DA Content}

We then examined the effect of lowered oxygen on the differentiation of dopaminergic neurons. The neural spheres expanded in either lowered or $20 \% \mathrm{O}_{2}$ and were then divided for differentiation. Precursors in lowered oxygen $\left(3 \% \mathrm{O}_{2}\right)$ resulted in $19.88 \pm 1.44 \% \mathrm{TH}$-positive cells, significantly higher than those in $20 \% \mathrm{O}_{2}(10.25 \pm$ $1.03 \%, \mathrm{n}=6, \mathrm{p}<0.01$; fig. $2 \mathrm{a}-\mathrm{c})$. Furthermore, the DA content of the medium in the lowered oxygen $\left(3 \% \mathrm{O}_{2}\right)$ group increased onefold compared with the control group 

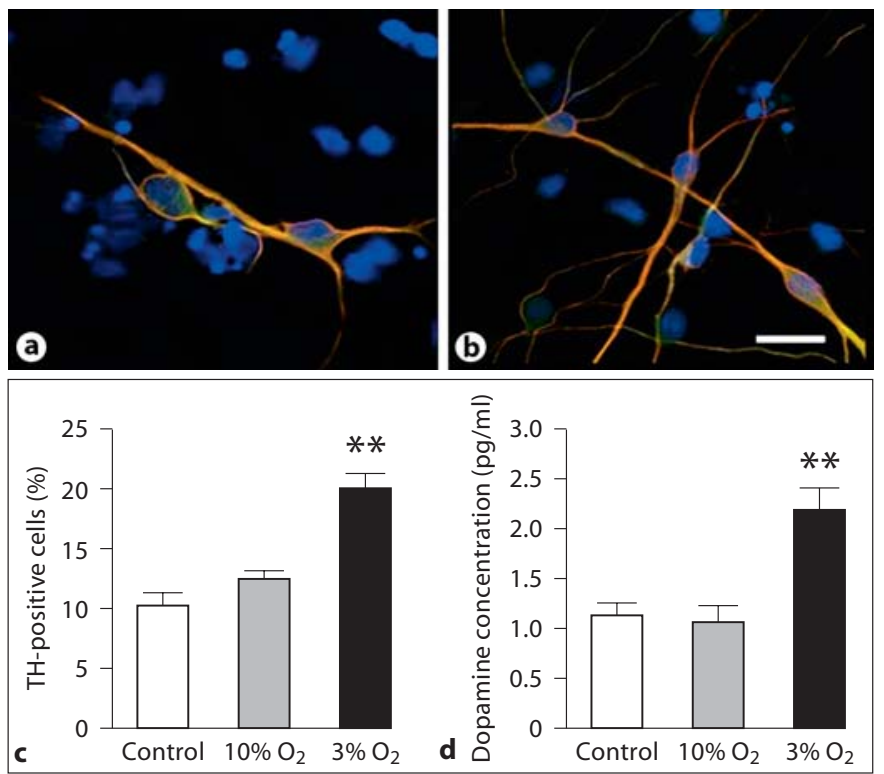

Fig. 2. Lowered oxygen increased the yield of TH-positive neurons and DA content. a Representative photograph of TH and Tuj1 double-labeled cells differentiated from NSCs under normal conditions. b Representative photograph of TH and Tuj1 double-labeled cells differentiated from NSCs under the $3 \% \mathrm{O}_{2}$ condition. Scale bar $=252 \mu \mathrm{m}$. c Diagram showing the number of TH-positive neurons. d Lowered oxygen increased the DA yield in supernatant detected by HPLC. Each bar represents the mean \pm SD $(\mathrm{n}=4) .{ }^{* *} \mathrm{p}<0.01$ as compared with control.

(fig. 2d). However, there was no significant difference in both TH-positive cells and DA content between the $10 \%$ $\mathrm{O}_{2}$ and control groups. These data suggest that NSCs under $3 \%$ oxygen tension increased the yield of $\mathrm{TH}$-positive neurons and DA content.

Effect of Lowered Oxygen on the Expression of HIF-1 $\alpha$ during Differentiation of NSCs

We next investigated the expression of HIF- $1 \alpha$ during differentiation of NSCs. NSCs were exposed to $20 \% \mathrm{O}_{2}$ or lowered oxygen ( 3 and $10 \% \mathrm{O}_{2}$ ) for 3 days, expression of HIF- $1 \alpha$ protein increased under the $3 \% \mathrm{O}_{2}$ condition compared with that under $10 \% \mathrm{O}_{2}$ and the control group, and weak expression of HIF-1 $\alpha$ protein could be detected under $10 \% \mathrm{O}_{2}$ (fig. 3a, b). Expression of HIF-1 $\alpha$ was then assayed by RT-PCR and Western blot, after the NSCs had been exposed to $20 \% \mathrm{O}_{2}$ or lowered oxygen $\left(3 \% \mathrm{O}_{2}\right)$ for 1 , $3,6,12,24,48$ and $72 \mathrm{~h}$. The data show that HIF-1 $\alpha$ mRNA was constitutively expressed under both the lowered oxygen and normal conditions (fig. 3c, d). There was no difference in the levels of HIF- $1 \alpha$ mRNA expression between control $\left(20 \% \mathrm{O}_{2}\right)$ and hypoxia $\left(3 \% \mathrm{O}_{2}\right)$. Lowered oxygen had no effect on the expression of HIF-1 $\alpha$ mRNA during differentiation of NSCs. However, a strong signal was observed in the groups with lowered oxygen $\left(3 \% \mathrm{O}_{2}\right)$ for $3 \mathrm{~h}$ which lasted for 3 days, whereas no HIF- $1 \alpha$ protein could be detected in the control. This indicates that HIF$1 \alpha$ might be involved in the differentiation of NSCs. We further investigated whether overexpression of HIF-1 protein by Ad/HIF- $1 \alpha$ could mimic the effects of lowered oxygen on the differentiation of NSCs under normal conditions.

\section{HIF-1 $\alpha$ Is Involved in Differentiation of NSCs into DA Neurons \\ Infection Rate of Cells Differentiating from NSCs Infected with $\mathrm{Ad} / \mathrm{HIF}-1 \alpha$}

The dissociated neural spheres were infected with Ad/HIF-1 $\alpha$ or empty virus (MOI $=50)$, and cultured under either lowered oxygen $\left(3 \% \mathrm{O}_{2}\right)$ or normal conditions for 3 days. Neurospheres were replanted in the 35$\mathrm{mm}$ dishes and differentiated for another 5 days under normal conditions. The efficiency of infection with adenovirus was calculated with the percentage of GFPpositive cells, and up to $85 \%$ GFP-positive cells are shown in figure $4 \mathrm{a}$ and $\mathrm{b}$. The expression of HIF- $1 \alpha$ protein in neural precursors was assayed by Western blot after infection. Overexpression of HIF-1 in NSCs under either 20 or $3 \% \mathrm{O}_{2}$ conditions was detected after infection with $\mathrm{Ad} / \mathrm{HIF}-1 \alpha$, as compared with the control, respectively (fig. 4c).

Overexpression of HIF- $1 \alpha$ Could Mimic the Effect of Lowered Oxygen on the Differentiation of NSCs under Normal Conditions

We further examined whether overexpression of HIF$1 \alpha$ could enhance the differentiation of NSCs into THpositive neurons. Under normal conditions, overexpression of HIF- $1 \alpha$ could also increase the percentage of THpositive cells, and increased about onefold as compared with the control. The percentage of TH-positive cells in the Ad/HIF-1 $\alpha$ infection under normal conditions had a twofold increase compared with the control. In addition, the percentage of TH-positive cells in Ad/HIF-1 $\alpha$ infection under the lowered oxygen condition also had a twofold increase as compared with control without Ad/HIF$1 \alpha$ infection (fig. 5). DA production by these neurons was confirmed by reverse-phase HPLC, which showed significantly increased levels of DA in hypoxia versus $20 \% \mathrm{O}_{2}$ cultures (fig. 6); conditioned medium showed a twofold increase in DA content $(n=5, p<0.01)$. These results demonstrate that overexpression of HIF- $1 \alpha$ could mimic 


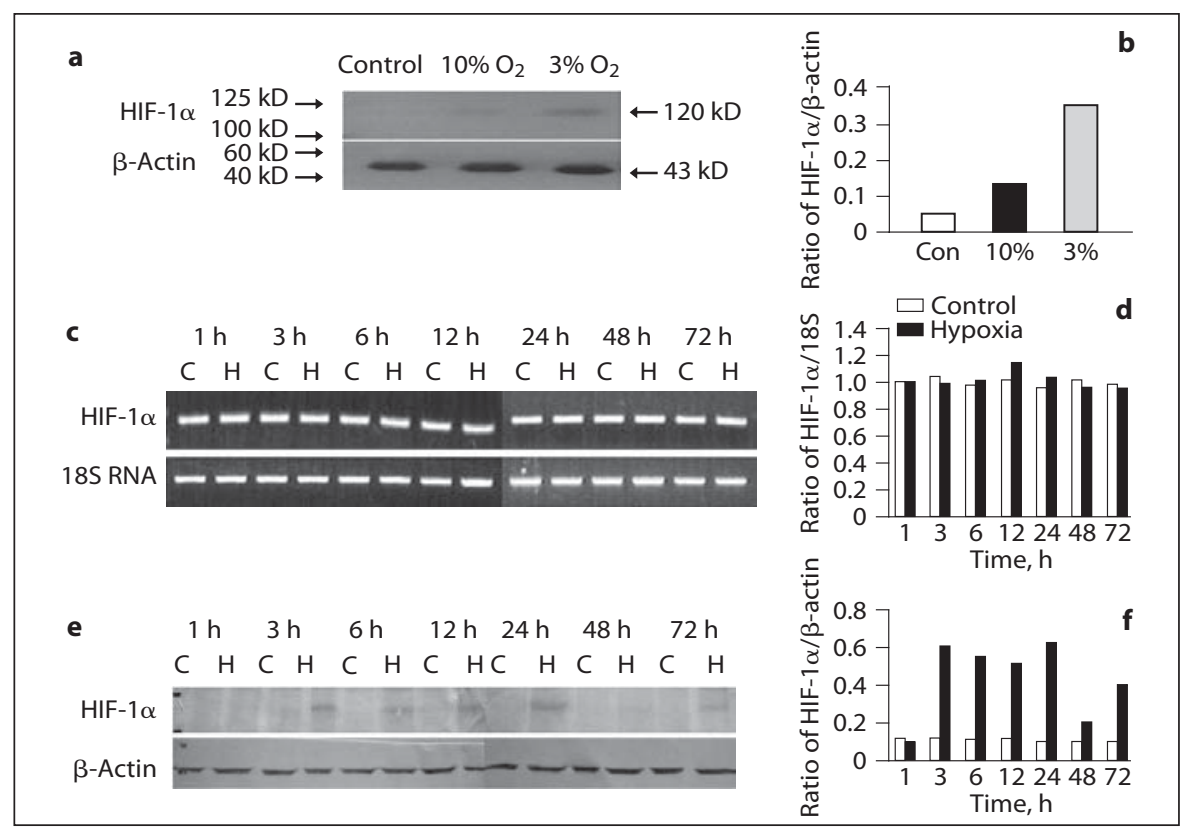

Fig. 3. Effects of lowered oxygen on the expression of HIF-1 $\alpha$ in NSCs. a Representative photograph of the expression of HIF-1 $\alpha$ protein detected by Western blot in NSCs at 3\% oxygen, $10 \%$ oxygen and normal conditions. b Semiquantitative analysis of the expression of HIF- $1 \alpha$ protein. Lowered oxygen $\left(3 \% \mathrm{O}_{2}\right)$ increased the levels of HIF-1 $\alpha$ expression compared with the $10 \%$ oxygen and control groups. c Representative photograph of the expression of HIF- $1 \alpha$ mRNA detected by RT-PCR. Cells were exposed to 20 or $3 \% \mathrm{O}_{2}$ for different periods of time. At the desired times, the cells were collected and RT-PCR analysis was performed on total RNA. d Semiquantitative analysis of the expression of HIF-
$1 \alpha$ mRNA. There was no difference in the levels of HIF-1 $\alpha$ mRNA expression between control $\left(20 \% \mathrm{O}_{2}\right)$ and hypoxia $\left(3 \% \mathrm{O}_{2}\right)$. e Representative photograph of the expression of HIF-1 $\alpha$ protein detected by Western blot. Cells were exposed to normoxia ( $\mathrm{C}=20 \%$ $\left.\mathrm{O}_{2}\right)$ or hypoxia $\left(\mathrm{H}=3 \% \mathrm{O}_{2}\right)$ for $1,3,6,12,24,48$ and $72 \mathrm{~h}$. Whole cell extracts $(100 \mu \mathrm{g})$ were analyzed by Western blot. A strong signal was observed in the hypoxia $(\mathrm{H})$ groups, whereas no HIF$1 \alpha$ protein could be detected in the control (C). $\mathbf{f}$ Semiquantitative analysis of the expression of HIF-1 $\alpha$ protein. Hypoxia (3\%) increased the expression of HIF- $1 \alpha$ protein. The expression of HIF$1 \alpha$ was normalized to that of $18 \mathrm{~S}$ RNA and $\beta$-actin $(n=3)$.
Fig. 4. Infection rate of cells differentiating from NSCs infected with Ad/HIF- $1 \alpha$. a Nucleus stained with DAPI. b Cells marked by GFP. Up to $85 \%$ of NSCs are GFP-positive cells. Scale bar $=200 \mu \mathrm{m}$. c Expression of HIF-1 $\alpha$ protein was detected in neural precursors by Western blot. NSCs infected with Ad/HIF-1 $\alpha$ or empty vector were exposed to 20 or $3 \% \mathrm{O}_{2}$ for 3 days. Expression of HIF-1 $\alpha$ after infection with $\mathrm{Ad} / \mathrm{HIF}-1 \alpha$ was higher than that in the control group.

Fig. 5. Overexpression of HIF-1 $\alpha$ promotes the differentiation of NSCs into TH-positive cells and DA content. a Cells double marked with GFP and PE detected by FACS. b Diagram of FACS. The percentage of TH-positive cells under normal conditions after infection with Ad/HIF-1 $\alpha$ was the same as under hypoxic conditions. Each bar represents the mean $\pm \operatorname{SD}(\mathrm{n}=4)$. ${ }^{* *} \mathrm{p}<0.01$ compared with control; ${ }^{\# \#} \mathrm{p}<$ 0.01 compared with hypoxia $\left(3 \% \mathrm{O}_{2}\right)$.
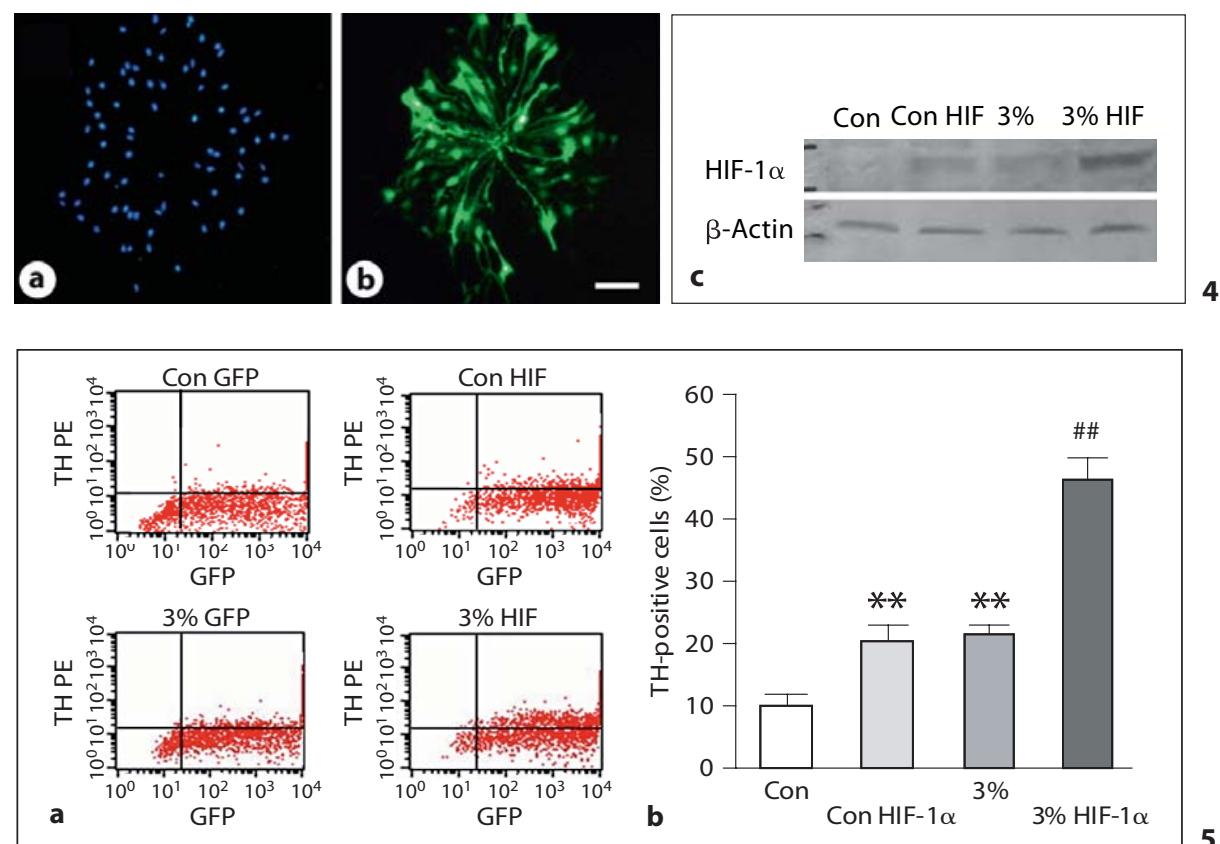


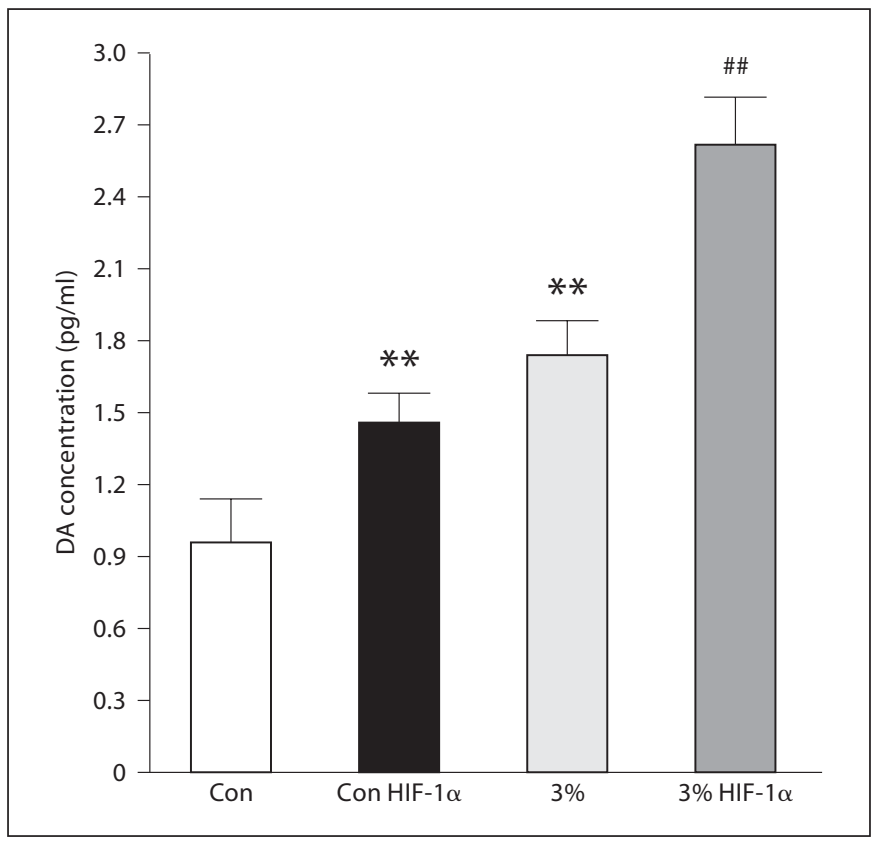

Fig. 6. Overexpression of HIF-1 $\alpha$ increased the DA yield in the supernatant. The content of DA in the supernatant was detected by HPLC. The DA content under normal conditions after infection with Ad/HIF-1 $\alpha$ increased significantly as compared with this in the empty vector group. Each bar represents the mean \pm $\mathrm{SD}(\mathrm{n}=4) .{ }^{* *} \mathrm{p}<0.01$ as compared with control; ${ }^{\# \#} \mathrm{p}<0.01$ as compared with hypoxia $\left(3 \% \mathrm{O}_{2}\right)$.

the effect of lowered oxygen $\left(3 \% \mathrm{O}_{2}\right)$ on the differentiation of NSCs, and HIF-1 $\alpha$ is involved in the production of DA neurons.

\section{Discussion}

In the present study, we identified the differentiation ability of NSCs expanded under lowered oxygen conditions, and found that these NSCs could differentiate into more neurons, especially more $\mathrm{TH}$-positive cells and higher DA yield in the medium. Overexpression of HIF$1 \alpha$ could mimic the effect of lowered oxygen on the differentiation of NSCs. These results demonstrate that $3 \%$ oxygen tension modifies the multi-lineage ability of the NSCs, and HIF- $1 \alpha$ is involved in the production of DA neurons.

The effects of lowered, more physiological $\mathrm{O}_{2}$ on the proliferation of stem cells are not limited to the CNS and extend to the peripheral nervous system $[1,2,5]$ and to non-neuronal tissues $[5,15,16]$. Hypoxia favors the THpositive cells of several kinds of stem cells, such as P19 cells, MSCs, ES cells [5, 11, 17], this provides a powerful tool for the generation of specific neuron types for clinic application. In particular, lowered $\mathrm{O}_{2}$ culturing has the practical effect of contributing to more efficient production of dopaminergic neurons for potential transplantation therapies.

Expression of the HIF-1 $\alpha$ mRNA and Protein in NSCs Induced by Hypoxia

It has been widely shown that HIF- $1 \alpha$ is activated in various cells under hypoxic conditions, and HIF- $1 \alpha$-targeted genes play an important role in maintaining cellular homeostasis in response to hypoxia $[12,13,18,19]$. However, study on the expression of HIF-1 $\alpha$ mRNA and protein in stem cells is limited. The mechanism of HIF$1 \alpha$ stabilization is regulated depending on the diversity of cell phenotypes or tissues.

It has been reported that HIF-1 $\alpha$ mRNA was ubiquitously expressed in the tissue and various cells; however, the HIF-1 $\alpha$ protein was soon degraded under normal conditions [20]. HIF-1 $\alpha$ is activated in ES cells under hypoxic conditions $\left(1 \% \mathrm{O}_{2}\right)$, and most of the HIF- $1 \alpha$ target gene expression is reduced in HIF- $1 \alpha^{-/-}$ES cells under hypoxia [22]. In our study, the results show that the expression of HIF-1 $\alpha$ mRNA in NSCs did not change 6$72 \mathrm{~h}$ after exposure to lowered oxygen (fig. 3c, d). Consistent with this, HIF-1 $\alpha$ mRNA is constantly expressed in muscle cells regardless of the culture conditions [7].

It is known that hypoxia induces the transcription of HIF- $1 \alpha$ mRNA that increases HIF- $1 \alpha$ protein in the presence of continued hypoxia. The activity of HIF- $1 \alpha$ is regulated mainly on the post-transcription level [20]. In normoxia, HIF- $1 \alpha$ is constitutively synthesized and sent to destruction by the ubiquitin-proteasome pathway (halflife $<5 \mathrm{~min}$ ). So HIF-1 $\alpha$ protein is absent or nearly absent in most normoxic cells. Consistent with this, we did not detect the expression of HIF- $1 \alpha$ protein in NSCs in normoxia. With the onset of lowered oxygen, we found that the level of HIF-1 $\alpha$ protein in NSCs was highly expressed. Therefore, these data suggest that the NSCs expanded under hypoxia highly express the HIF- $1 \alpha$ protein, and this may be a critical mechanism by which hypoxia regulates the fate of NSCs.

\section{HIF-1 $\alpha$ Is Involved in DA Differentiation of NSC \\ Induced by Hypoxia}

In this study, we show that the differentiation ability of NSCs under hypoxia has been modified, which results in NSCs differentiating into more TH-positive cells. Precursors in hypoxia resulted in $19.88 \pm 1.44 \% \mathrm{TH}$-posi- 
tive cells, significantly higher than those in $20 \% \mathrm{O}_{2}(10.25$ $\pm 1.03 \%, \mathrm{n}=6, \mathrm{p}<0.01$; fig. 2). However, Studer et al. [2] treated NSCs with $3 \%$ oxygen and induced $56 \%$ dopaminergic phenotype differentiation. The main discrepancy as compared with our study is that they added BMP2 to the differentiation medium, while it is known that BMP2 could promote the formation of neurons. The above results indicate that exposure to hypoxia confined to the differentiation phase does not significantly increase the percentage of neurons expressing TH of NSCs in vitro. This suggests the important effects of hypoxia in promoting dopaminergic differentiation in the proliferation phase but not in the differentiation phase. Because HIF$1 \alpha$ is highly expressed in the NSCs expanded under hypoxic conditions, we investigated the role of HIF-1 $\alpha$ in the regulation of the NSCs phenotype. We used Ad/virus HIF-1 $\alpha$ to specifically upregulate the expression of HIF$1 \alpha$ protein, and the results showed that NSCs are able to undergo dopaminergic differentiation under normal conditions when HIF-1 $\alpha$ is overexpressed by $\mathrm{Ad} /$ virus HIF- $1 \alpha$. Importantly, overexpression of HIF- $1 \alpha$ could partially mimic the effects of hypoxia on the DA neuron yield derived from NSCs.

Taken together, we have demonstrated for the first time that the HIF-1-signaling pathway is activated in NSCs by lowered oxygen and plays an important role in hypoxia-induced NSCs differentiation. This indicates that the differentiation ability of NSCs is determined during the expansion of NSC under lowered oxygen.

\section{Acknowledgments}

This work was supported by the National Basic Research Program of China (No. 2006CB504100) and a key grant from the Nature and Sciences Foundation of China (No. 30393130).

\section{References}

1 Morrison SJ, Csete M, Groves AK, Melega W, Wold B, Anderson DJ: Culture in reduced levels of oxygen promotes clonogenic sympathoadrenal differentiation by isolated neural crest stem cells. J Neurosci 2000;20: 7370-7376.

$\checkmark 2$ Studer L, Csete M, Lee SH, Kabbani N, Walikonis J, Wold B, McKay R: Enhanced proliferation, survival, and dopaminergic differentiation of CNS precursors in lowered oxygen. J Neurosci 2000;20:7377-7383.

-3 Marks JD, Bindokas VP, Zhang XM: Maturation of vulnerability to excitotoxicity: intracellular mechanisms in cultured postnatal hippocampal neurons. Dev Brain Res 2000;124:101-116.

4 Li D, Jeremy D, Marks PT, Schumacker RM, James RB: Physiological hypoxia promotes survival of cultured cortical neurons. Eur J Neurosci 2005;22:1319-1326.

$\checkmark 5$ Zhu LL, Wu LY, Yew DT, Fan M: Effect of hypoxia on the proliferation and differentiation of NSCs. Mol Neurobiol 2005;31:231242.

-6 Ramirez-Bergeron DL, Runge A, Dahl KD, Fehling HJ, Keller G, Simon MC: Hypoxia affects mesoderm and enhances hemangioblast specification during early development. Development 2004; 131:4623-4634.

7 Yun Z, Lin Q, Giaccia AJ: Adaptive myogenesis under hypoxia. Mol Cell Biol 2005;25: 3040-3055.
8 Yun Z, Maecker HL, Johnson RS, Giaccia AJ: Inhibition of PPAR gamma 2 gene expression by the HIF-1-regulated gene DEC1/ Stra13: a mechanism for regulation of adipogenesis by hypoxia. Dev Cell 2002;2:331341.

$\checkmark 9$ Lin Q, Lee YJ, Yun Z: Differentiation arrest by hypoxia. J Biol Chem 2006;281:3067830683.

10 Zhu LL, Zhang CP, Zhao T, Li HS, Zhao HQ Fan M: Effect of hypoxia on the proliferation and differentiation of NSCs. Xilin International Symposium on Neurodegenerative Diseases and Stroke (BINS-2), 2004, pp 4142.

11 Jin B, Wu LY, Zhao T, Wu HT, Zhu LL, Fan $\mathrm{M}$ : Hypoxia enhanced the differentiation of P19 cells into DA neurons. Basic Clin Med 2006;26:1205-1209.

12 Huang LE, Gu J, Schau M, Bunn HF: Regulation of hypoxia-inducible factor $1 \alpha$ is mediated by an $\mathrm{O}_{2}$-dependent degradation domain via the ubiquitin-proteasome pathway. Proc Natl Acad Sci USA 1998;95:79877992.

13 Semenza GL: Expression of hypoxia-inducible factor 1: mechanisms and consequences. Biochem Pharmacol 2000;59:47-53.

14 Zhu L, Onaka T: Involvement of medullary A2 noradrenergic neurons in the activation of oxytocin neurons after conditioned fear stimuli. Eur J Neurosci 2002;16:2186-2198.

-15 Ren H, Cao Y, Zhao Q, Li J, Zhou C, Liao L, Jia M, Cai H, Han ZC: Proliferation and differentiation of bone marrow stromal cells under hypoxia conditions. Biochem Biophys Res Commun2006;347:12-21.
16 Xie XJ, Wang JA, Cao J, Zhang X: Differentiation of bone marrow mesenchymal stem cells induced by myocardial medium under hypoxic conditions. Acta Pharmacol Sin 2006;27:1153-1158.

- 17 Zeng X, Cai J, Chen J, Luo Y, You ZB, Fotter E, Wang Y, Harvey B, Miura T, Backman C, Chen GJ, Rao MS, Freed WJ: Dopaminergic differentiation of human embryonic stem cells. Stem Cells 2004;22:925-940.

18 Bergeron M, Yu AY, Solway KE, Semenza GL, Sharp FR: Induction of hypoxia-inducible factor-1 (HIF-1) and its target genes following focal ischaemia in rat brain. Eur J Neurosci 1999;11:4159-4170.

19 Salceda S, Caro J: Hypoxia-inducible factor lalpha (HIF-1alpha) protein is rapidly degraded by the ubiquitin-proteasome system under normoxic conditions. Its stabilization by hypoxia depends on redox-induced changes. J Biol Chem 1997;272:2264222647.

20 Huang LE, Bunn HF: Hypoxia-inducible factor and its biomedical relevance. J Biol Chem 2003;278:19575-19578.

$>21$ Adelman DM, Simon MC: Hypoxic gene regulation in differentiating ES cells. Methods Mol Biol 2002; 185:55-62.

$>22$ Ramirez-Bergeron DL, Simon MC: Hypoxia-inducible factor and the development of stem cells of the cardiovascular system. Stem Cells 2001;19:279-286. 